American Journal of Applied Sciences 6 (4): 709-714, 2009

ISSN 1546-9239

(C) 2009 Science Publications

\title{
Albian-Cenomanian Zonation (Foraminifers and Calcareous Aglae) in the Northern Fars, Iran
}

\author{
Mahnaz Parvaneh Nejad Shirazi \\ Shiraz Payame Noor University, Saheli St., Shiraz, Iran
}

\begin{abstract}
Problem statement: In the middle Cretaceous of Iran, fossil calcareous algae and zonation them with foraminifers are one of the less studied compared to others invertebrate groups such as foraminiferis, mollusks and others. Several stratigraphic units were analyzed in detail and a biostratigraphic zonation of the Albian-Cenomanian rocks of the Fars basin (Sw. Iran) is proposed. Approach: All stratigraphic units were studied for the determination calcareous algae accompanying with foraminifers. Identification of planktonic, benthic foraminifers and calcareous algae was made from thin slides. After the identification of the microfossils assemblages, benthic, planktonic microfossil and calcareous algae biostratigraphy was recognized and a possible correlation with the other zonations was established. Results: The stratigraphic distribution of 21 genus of calcareous algae and benthic and planktonic foraminifers is used to characterize 4 ass. zone that in ascending order are: Or. aperta-Cuneolina ass. zone, Or. conica-Hemicyclammina ass. zone, Dicyclina-Orbitolina ass. zone and Alveolinids ass. zone. The top of Or. aperta-Cuneolina ass. zone is marked at the last appearance of the marker fossil. The Or. conica-Hemicyclammina ass. zone was defined with the last appearance of Or. conica and represented by an assemblage characterized by Cuneolina pavonia-Hemicyclammina sigali-Pseudochrysalidina sp. together with calcareous algae such as: Trinocladus tripolitanusPermocalcus irenae. Overmost of the area, the transition from shallow-marine limestones up into pelagic facies occurs within the R. appenninica-Radiolaria ass. Zone. The Orbitolina-Dicyclina ass. zone is recognized in the Sarvak Formation and is represented by an assemblage characterized by Nezzazata simplex-Neoiraqia convexa-Hemicyclammina sigali together with Permocalculus irenea. Toward the central and western part of the area in shallow marine facies, this zone is changed to the Alveolinids zone which corresponds to the last appearance of Simplalveolina. Conclusion/Recommendation: Therefore, calcareous algae can be an important source of introducing ass. zones.
\end{abstract}

Key words: Albian, cenomanian, foraminifera, algae, fars, Iran

\section{INTRODUCTION}

The Zagros mountain ranges dominate southwestern Iran.. The sediments exposed here are generally of Mesozoic age. The intensity of folding gradually decreases towards the Persian Gulf where younger rocks are seen in outcrop.

Fars province holds many diverse morphological features with accommodates will with its geological characteristics.

The areas north and northeast of this province are composed of continuous high mountains range with deep incised valleys, while south and southwest part is characterized by existing intermountainous plains like Shiraz, Kazerron and others which are irrigated by several rivers. These rivers join finally to internal lakes like Bakhtegan.
Geographically the Zagros mountains belong to the Alpine-Himalayan chain, but clearly do not fit into models for the Alps or Himalayas ${ }^{[13]}$. Some of these difficulties were discussed by Stocklin ${ }^{[12]}$, who concluded that Iran had a peculiar type of Alpine tectonics.

Previous biostratigraphic studies: Cretaceous marine sediments exposed in several localities in the Fars basin of Sw Iran. Although several geologists have studied these rocks, the biozonation of the Cretaceous succession using larger foraminiferal and algal assemblages zones have received very little attention.

Until recently there have been few stratigraphic units studies of middle Cretaceous sediments of Shiraz area, Sw Iran. One of the earliest is that by Henson ${ }^{[9]}$, Who in his work on "larger imperforate foraminifera of $\mathrm{Sw}$ Asia" included some Orbitolina from kuh-e- 
Banish, Sw Iran. The first modern work was carried out by Gollestaneh ${ }^{[8]}$ who studied the micropaleontology of the Khami Group (Early Jurassic-Aptian) as represented in southern Iran. Assemblage zones of relatively short range were discussed in his study with boundaries marked by changes in fossil content.

The sequence of algal species in Edgell's zones is generally similar to that of southern Europe, as described by Carrozzi $^{[3]}$. Vaziri Moghaddam ${ }^{[14]}$ described the biostratigraphy of the Sarvestan area of southern Iran using foraminiferal assemblages in thinslide and washing samples.

Stratigraphy: The number of outcrops exposing the entire Cretaceous sequence is very limited. The middle Cretaceous in the Zagros basin is represented by two types of faces:

- The first type is exposed at Fars and SE Khuzestan, Where middle Cretaceous sedimentation began with deposition of shallow water limestones (Kazhdumi Formation) and continued through most of Albian time. This Formation lie uncomfortably on the Dariyan Formation. The upper boundary of the Kazhdumi Formation with the overlying marly thin bedded limestone of the Sarvak Formation is an unconformity over the greater portion of Fars province, south Shiraz and north of that

- The second type of middle Cretasceous succession in the Zagros basin is found in Lurestan, where the middle Cretaceous is represented by dark, grey to black radiolarian bearing shales and argillaceous limestones of deeper water origin (Garu Formation)

The middle Cretaceous Bangestan Group in the Central Zagros is one of the major carbonate petroleum systems of the Middle East with the Khazdumi source rocks underlying the Sarvak and Ilam shallow water carbonates (reservoirs).

This lithostratigraphy follows that of James and wynd $^{[11]}$. The sub-units recognized in this study are identified on the basis of lithology, petrography and paleontology. The petrographic classification of rocks is according to Folk's carbonate rock classification ${ }^{[7]}$, in addition to Dunham classification ${ }^{[5]}$ and Wright classification $^{[15]}$.

Kazhdumi Formation: It consists of 690 feet of dark bituminous shale with subordinate, dark orgillaceous limestone. Glauconite is common, particularly in the lower 300 feet. The basal 100 feet contains numerous red, oxidized zones.
Contact with the underlying cherty limestone of the Dariyan Formation is associated with red zones indicative of shallowing or a possible diastem. The upper contact grades into the marly, thin-bedded limestone of the basal part of the Sarvak Formation. The Kazhdumi Formation is generally Albian to early Cenomanian in age.

Biostratigraphy of the Kazhdumi Formation: James and wynd ${ }^{[11]}$ studied rocks of the Kazhdumi Formation and on the basis of the presence of Parahoplites they assigned a Late Aptian age for the base of the Formation. The fossil content that they reported for this unit include Favusella washitensis and rich floods of Oligostegina occur throughout the upper 450 feet of the formation. The basal 240 feet contains a rich founa of Hedbergella sp.- Ticinella sp., Biglobigerinella sp. and Planomalina sp. with Radiolaria and spicules. Hemicyclammina cf. sigali and Orbitolinides are also found in the basal beds.

They also studied the macrofauna of the formation and assigned an age of Late Albian for the base of the formation by the presence of Parahoplites in a few localities. The Kazhdumi Formation is generally Albian to early Cenomanian in age.

Sarvak Formation: The lower 835 feet is composed of fine grained, dark gray, nodular-bedded argillaceous limestone with thin, dark gray marl partings. Small ammonite impressions are common throughout. This grades upward into a massive, chalkey white to buff limestone 360 feet thick with numerous brownish red, siliceous nodules.

Above the siliceous unit is 1360 feet of very massive, tan to brown limestone containing abundant ruddiest debris. Large scale cross bedding is present in the basal part. The upper 140 feet of the formation is made up of 2/5-7-5 cm beds of rubbly, relatively low weathering limestone with ferruginous red steining and Leached zones of breccia. The top is very ferruginous uneven and rubbly.

The contact with the underlying Kazhdumi Formation is gradational and conformable. The upper contact with the Gurpi formation is uneven and associated with a rubbly weathered zone.

Biostratigraphy of the Sarvak Formation: The fossils that James and wynd ${ }^{[11]}$ reported for this unit include microfossils (planktonic and benthic forminifers). The plaonktonic foraminifers reported by them in the basal 835 feet of nodular, marly limestone contain an abundant "Oligostegina"-Favusella founa associated with Rotalipora sp. and Hedberglla sp. 
The species of the benthic foraminifers reported by them of the overlying 1360 feet of massive, rudestbearing limestone include Prealveolinea cretacea, Ovalveolina sp., Nezzazata sp., Rabanitina sp., rare Orbitolina sp., Dictyoconella sp. and Dicyclina sp. In the uppermost of rubbly limestones this fauna becomes more abundant with rich occurences of Ovalveolina ovum-Cisalveolina sp. Cuneolina sp., Meandropsina sp., Taberina sp. Based on the fossil assemblage they assigned them a Albian to Cenomanian and possibly to Turonian age.

\section{MATERIALS AND METHODS}

Stratigraphic units (Fig. 1) were analyzed in detail. These units were measured in the whole part of the Kazhdumi and Sarvak formations. Additional samples from other localities were collected in isolated outcrops in order complete my understanding of faces variation and age. Identification of planktonic, benthic foraminifers and calcareous algae was made from thin slides. For the determination of calcareous algae, the ${\text { criteria of Bassoullet et al } .^{[1,2]} \text {, Deloffre }}^{[6]}$ and Yilmaz ${ }^{[16]}$ were followed. The benthic foraminifers were identified according to the criteria of Husinec et $a l^{[10]}$.. The identification of planktonic forminifers was based on Caron $^{[3]}$. A chart with the total ranges of the identified fossils was constructed (Fig. 2).

After the identification of the microfossils assemblages, benthic, planktonic microfossil and calcareous algae biostratigraphy was recognized and a possible correlation with the other zonations was established (Fig. 3).

\section{RUSULTS AND DISCUSSION}

In dating and correlation in the middle Cretaceous rocks studied, entire foraminifers and calcareous algae assemblages have been taken into account. The 4 proposed zonal scheme is based on the total ranges of 21 selected species of identified during this study (Fig. 2). In the present system of zonation, zones are based on:

- Combination of taxon ranges

- Concurrences of taxon ranges

- The distinctive first and last occurrences of taxal and relatively short-ranging assemblages of foraminifera

- It should be noted that this biozonation scheme is of value only in local correlation studies. It should be considered as the starting point for developing a more regionally applicable scheme

Further discussion of this biozonation scheme is given below. For each of the biozones, a definition is given together with comments on distribution in the studied sections, assemblage characteristics.

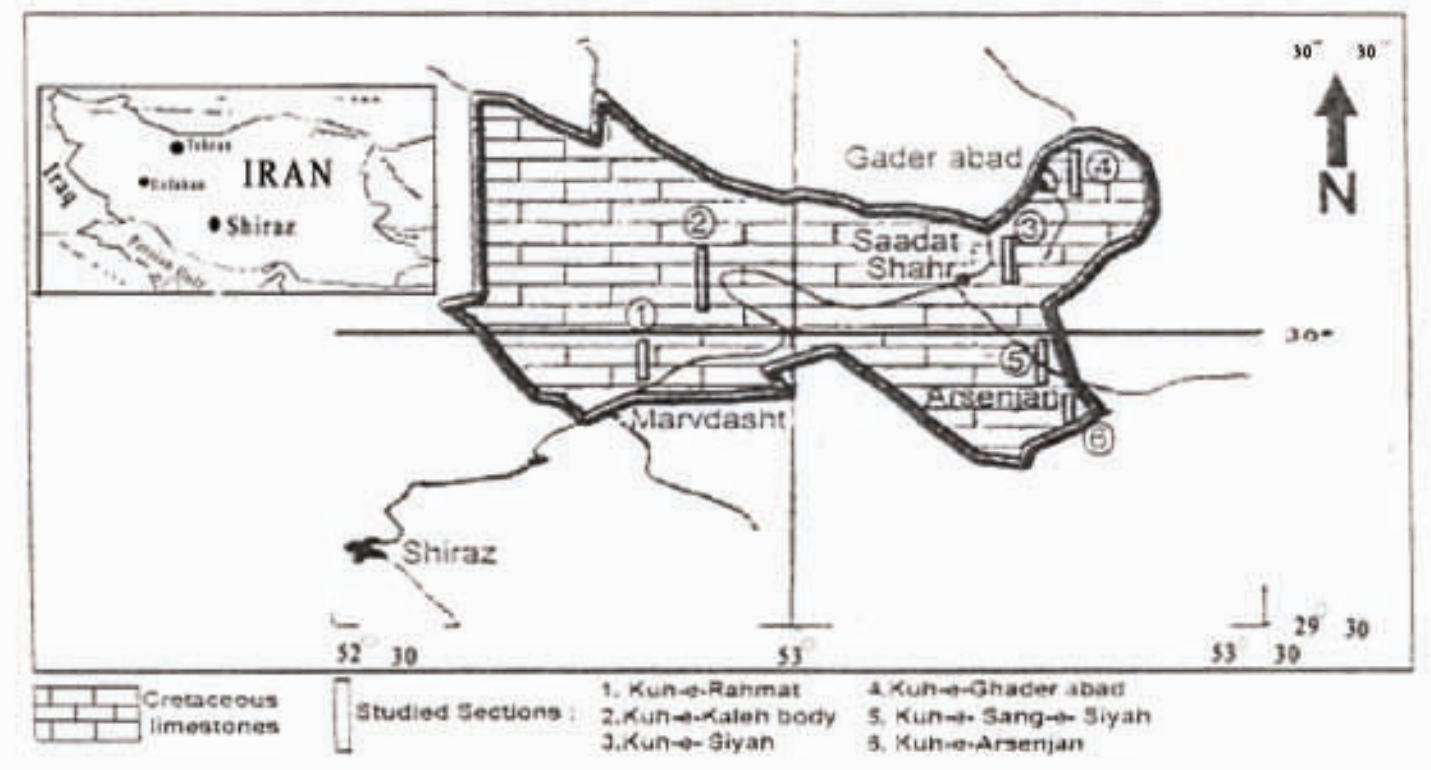

Fig. 1: Location map of the studied area 
Orbitolina aperta-Cuneolina ass. zone:

Definition: To defined by the local extinction level of the nominate taxon, base by the local inception level of the nomicate taxon.

Distribution: Kuh-e-siyah, Kazhdumi Formation.

Assemblage characteristics: Significant microfossils recorded from this zone include Orbitolina conica d' Archiac, Or. aperta Ermann, Hemicyclammina sigali maync.

Chronostratigraphic significance: The presence of Or. aperta indicates that this assemblage zone is of Late Albian-Early Cenomanian age.

\section{Orbitolina conica-Hemicyclammina ass. zone:}

Definition: Top defined by the local extinction level of the nominate taxon, base by the local inception level of the nominate taxon.

Distribution: kuh-e-siyah, Kazhdumi Formation and Sarvak Formation.

Assemblage characteristics: Significant microfossils recorded from this zone include Cuneolina pavonia (d' Orbigny), Neoiraqia convexa Daniloca, Hemicyclammina sigali Maync, Pseudochrysalidina sp. and calcareous algae such as: Trinocladus tripolitanus Raineri \& Permocalculus irenae Elliott.

Chronostratigraphic significance: The presence of Or. conica indicates an Late Albian-Early Cenomanian age.

\section{Rotalipora appeninica-Radiolaria ass zone:}

Definition: Top defined by the local extinction level of the nominate taxon, base by the local inception level of the nominate taxon.

Distribution: Kuh-e-Naghsh-e-Rostam, kuh-e-siyah, Sarvak Formation.

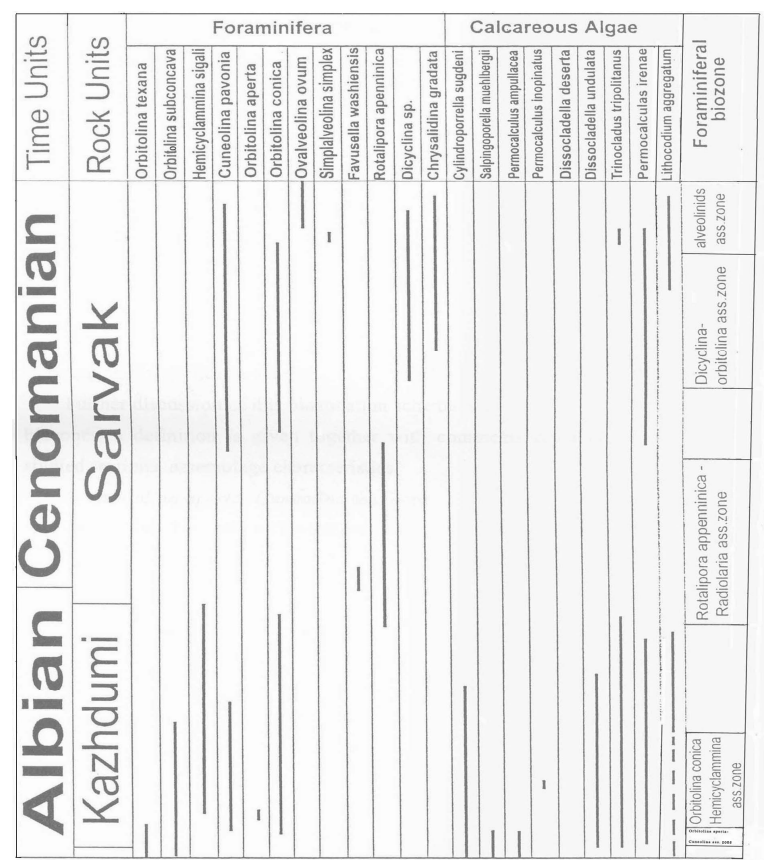

Fig. 2: The biozonation scheme of the studied areas showing the zones and stratigraphic distribution of main microfossils
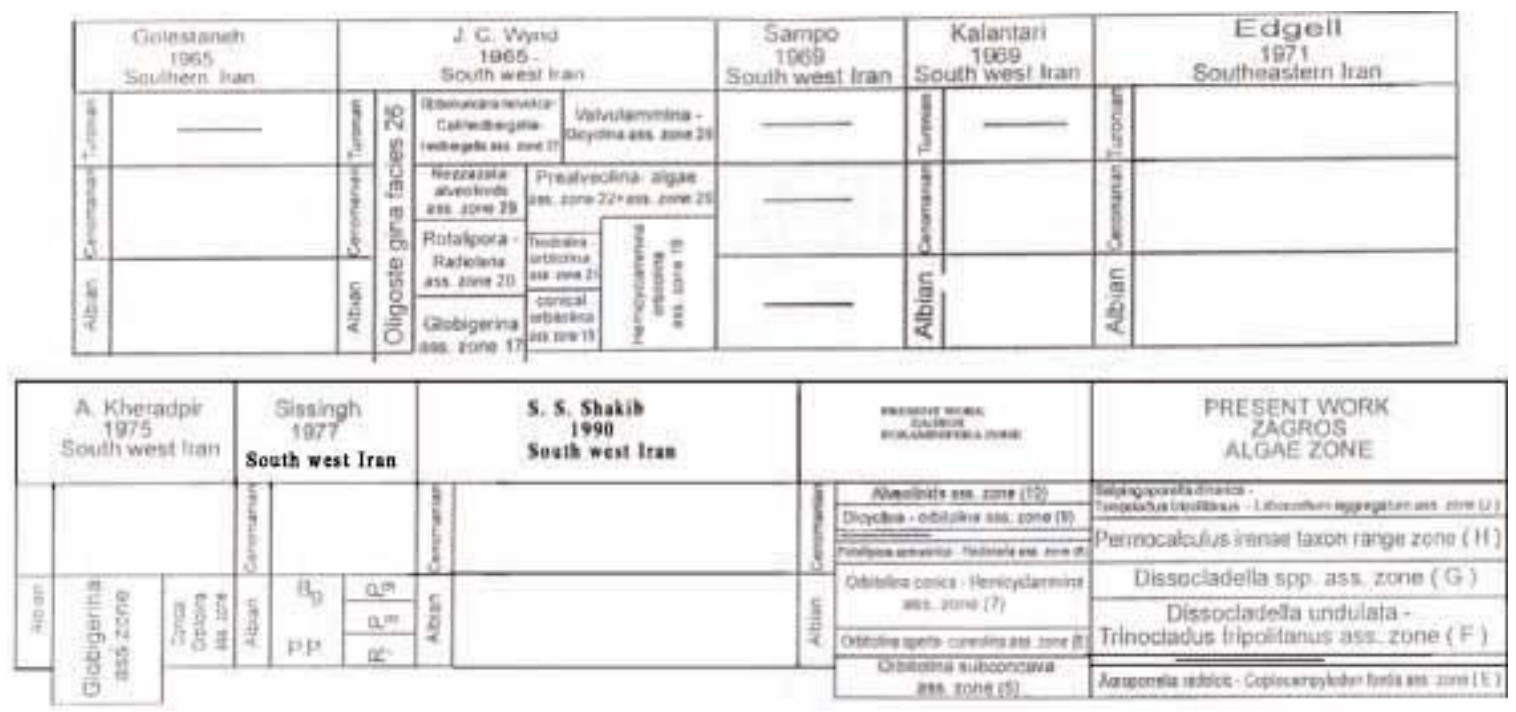

Fig. 3: Showing a comparison of zonation of calcareous algae and foraminiferal in the studied area with others 
Assemblage characteristic: Significant microfossils recorded from this zone include $R$. appenninica (Renz), H. Planispira (Tappan), H. trochoidea (Gandolfi), Calcisphaerula innominata Bonet, Stomiospharea sphaerica Kaufman, S. conoidea, Bonet.

Choronostratigraphic significance: The presence of $R$. appeninica indicates an Early Cenomanian age. This age assignment is supported by the age of the overlying ass zone.

\section{Orbitolina-Dicyclina ass.zone:}

Definition: This zone defined by the local abundance of the nominate taxon.

Distribution: Kuh-e-Rahmat, middle part of Sarvak Formation.

Assemblage characteristic: Significant microfossils recorded from this zone include Nezzazota simplex Omara, Cuneolina Pavonia d' Orbigny, Neoiraqia convexa, Pseudolituonella sp., Hemicyclammina sigali maync.

Choronostigraphic significance: This ass. zone indicates middle-late Cenomanian age. This age assignment is supported by the age of the underlying ass. zone.

Alveolinids ass. Zone:

Definition: Top defined by the local extinction level of Simplaveolina simplex-base by the local inception level of the fossil.

Distribution: Kuh-e-Rahmat upper part of Sarvak Formation.

Assemblage characteristic: Significant microfossils recorded from this zone include Dicyclina sp., Cuneolina pavonia d'orbigny, Or . sp.

Chronostratigraphic significance: The local extinction level of $S$. simplex indicate middle-Late Cenomanian age.

\section{CONCLUSION}

A biostratigraphic zonation of the AlbianCenomanian rocks of the Fars basin (Sw. Iran) has been determined in this research. The stratigraphic distribution of 21 genus of calcareous algae and benthic and planktonic foraminifers is used to characterize 4 ass. zone. A combined foraminiferal and calcareous algae is proposed for the Albian-Cenomanian succession of the Fars basin. The disappearance of the zonal marker foraminifers defines the top of the later zone.

\section{ACKNOWLEDGMENT}

This research formed parts of MS thesis at Payame-Noor University. I think the students of Shiraz Payame noor University for physical support during my fieldwork.

\section{REFERENCES}

1. Bassoullet, J.P., P. Bernier, R. Deloffre, P. Genot, M. Jaffrezo and A.F. Poignant, 1975. Reflexions sur la systematique des dasycladales fossils. Geobios, $\quad 8$ 2: 259-290. http://www.sciencedirect.com/science?_ob=Article URL\&_udi=B6X0V-4JK56DX-

2. Bassoullet, J.P., P. Bernier, M.A. Conrad, R. Deloffre and M. Jafrezo, 1978. Les algues dasycladales du Jurassique et du Cretace. Geobios Memoire Special, 11: 11-330.

http://www.sciencedirect.com/science?_ob=Public ationURL\&_tockey=\%23TOC\%237224\% 231978

3. Carrozzi, A.V., 1989. Carbonate Rock Depositional Models: A Microfades Approach. Prentice Hall, Englewood Cliffs, New Jersey, ISBN 0-13-114398-0, pp: 604.

4. Caron, M., 1985. Cretaceous Planktonic Foraminifera. In: Planktonic Stratigraphy, Bolli, H.M., Saunders and K. Nielsen (Ed.). Cambridge University Press, New York, USA., pp: 17-86. http://taxonconcept.stratigraphy.net/source_main.p hp?document_id=729\&PHPSESSID $=3 \mathrm{ae} 93 \mathrm{faa} 4 \mathrm{c} 6$ $4 \mathrm{c} 99 \mathrm{c} 93 \mathrm{ef} 5 \mathrm{c} 2 \mathrm{aa} 0243 \mathrm{e} 38$

5. Dunham, R.J., 1962. Classification of carbonate rocks according to depositional texture. In classification of carbonate rocks. Am. Assoc. Petrol. Geol. Bull., 43: 1-38.

6. Deloffre, R., 1988. Nouvelle taxonomic des algues dasycladales (New Taxonomy of Dasycladale Algae). Bull. Centres Rech Explor-Prod. ElfAquitaine, 12: 165-217. http://www.antiqbook.nl/boox/aquila/2045.shtml

7. Folk, R.L., 1959. Practical petrographic classification of limestone. Bull. Amer. Assoc. Petrol. Geol., 43: 1-38. http://aapgbull.geoscienceworld.org/cgi/content/ab stract $/ 43 / 1 / 1$ 
8. Gollestaneh, A., 1966. An introduction to the stratigraphic distribution of fossil Calcareous algae in southern Iran. Iranian oil operating companies geological and explo. division

http://www.nioclibrary.ir/simwebclt/WebAccess/Si mwebPortal.dll

9. Henson, F.R.S., 1948. Larger imperforate Foraminifera of Southwestern Asia. Families Lituolidae, Orbitolinidae and Meandropsinidae. British Museum (Natural History), London, pp: 127. http://catalogue.bl.uk/F/PKSC5BKG4E772APAM HBTVGMGYXEHH28X41RYS7D6VNUTR9NI8 $\mathrm{N}-25506$ ?func $=$ full-setset\&set_number $=000998 \&$ set_entry $=000002 \&$ for mat $=999$

10. Husinec, A., I. Velic, L. Fucek, I. Vahovic, D. Maticec, N. Ostric and T. Korbar, 2000. Mid cretaceous orbitolinid (Foraminiferda) record from the islands of Cres and Losinj (Croatia) and its regional stratigraphic correlation. Cretaceous Res., 21: 155-171. DOI: 10.1006/cres.2000. 0203

11. James, G.A. and J.G. wynd, 1965. Stratigraphic Nomen clature of Iranian oil consortium agreement area. Bull. Am. Assoc. Petrol. Geol., 49: 2192-2245. http://aapgbull.geoscienceworld.org/cgi/content/ab stract/49/12/2182
12. Stocklin, J., 1968. Structural history and tectonics of Iran. Bull. Am. Assoc. Petrol. Geol., 52: 1239-1258. http://aapgbull.geoscienceworld.org/cgi/content/ab stract/52/7/1229

13. Takin, M., 1972. Iranian geology and continental drift. Nature, 235: 147-150. DOI: $10.1038 / 235147 \mathrm{a} 0$

14. Wray, J.L., 1977. Calcareous algae. Develop. Paleontol. Biostratigrap., 4: 185. Elsevier, Amsterdam.

15. Vaziri Moghddam, H., 2002. Biostratigraphic studyof the Ilam and Gurpi formations based on planktonic foraminifera in SE of Shiraz, Iran. J. Sci., 13: 339-356. http://sid.ir/en/VEWSSID/J_pdf/97320020406.pdf

16. Wright, V.P., 1992. A revised classification of limestone. Sediment. Geol., 76: 177-184. http://cat.inist.fr/?aModele=afficheN\&cpsidt=5529 993.

17. Yilmaz, I.O., 1999. Taxomonic and paelogeographic approaches to the dasyclad algae in the Upper Jurassic-Upper Cretaceous Peritidal carbonate of the fele area, Turkey. Turk. J. Earth Sci., $\quad 8: \quad 1-101$. http://journals.tubitak.gov.tr/earth/issues/yer-99-82-3/yer-8-2-3-1-98034.pdf 